Arab Univ. J. Agric. Sci., Ain Shams Univ., Cairo, 13(2), 327-339, 2005

\title{
CORRELATION AND PATH COFFICIENT ANALYSIS IN FOUR YELLOW MAIZE CROSSES UNDER TWO PLANTING DATES \\ [20]
}

\author{
El-Shouny $^{1}$, K.A.; Olfat. H. El-Bagoury ${ }^{1}$; K.I.M. Ibrahim ${ }^{1}$ and S.A. Al-Ahmad ${ }^{1}$
}

\begin{abstract}
$F_{1}$ and $F_{2}$ seeds of four crosses were formed during 2001 and 2002 growing seasons. The $\mathrm{F}_{2}$ population's plants were evaluated during 2003 growing season under the two planting dates ( $14^{\text {th }}$ May and $29^{\text {th }}$ June) to estimate the phenotypic correlation coefficients among eight plants characters and their contributions in the variation of grain yield/ plant at the Agric. Res. Stat. of Fac. of Agric., Ain Shams Univ., Shalakan, Kalubia Governorate, Egypt. Results showed that grain yield/ plant under normal planting date correlated positively and significantly - in most cases - with each of ear diameter, ear length, number of kernels/ row, 100-kernel weight, number of rows/ ear, ear height, plant height and days to silking, while under late planting date, it correlated with each of number of kernels/ row, ear diameter, 100-kernel weight, ear length, number of rows/ ear, ear height and days to silking. Path coefficient analysis estimates indicated that ear diameter; ear length and number of kernels/ row can be considered as the most important sources of plant grain yield variation under normal planting date while, under late planting date they were number of kernels/ row, ear diameter, 100-kernel weight and ear length. It was concluded that each of ear diameter, ear length and ear length through its indirect effects via ear diameter are considered as the most important sources of plant grain yield variation.
\end{abstract}

Key words: Maize, Planting date, Correlation and Path coefficient analysis

\section{INTRODUCTION}

The association between characters is very important and gives very useful information to the crop breeders. If two characters are significantly correlated either positively or negatively, the selection for any of them will cause a change in the other depending on the correlation strength. The magnitude of association between yield contributing characters in terms of their direct and indirect effects on maize grain yield/ plant is of a great value for maize breeding programs. The path coefficient analysis indicates the most promising yield attributes which contribute directly to the final yield. Grain yield was reported to be significantly and positively correlated with each of number of rows/ ear, ear length, number of kernels/ row and 100-kernel weight (Abd El-Aty and Katta, 2002). Signifi-

1- Department of Agronomy, Faculty of Agriculture, Ain Shams University, Shoubra El-Kheima, Cairo, Egypt 
cant positive correlation was recorded between grain yield and each of ear length, number of kernels/ row and number of rows/ ear, while 100-kernel weight was negatively correlated with grain yield/ plant (El-Beially, 2003). Mohamed (2003) indicated that grain yield was correlated positively and significantly with each of ear length, ear diameter, number of kernels/ row, 100-kernel weight, plant height, ear height and days to silking. Alvi et al (2003) concluded that number of kernels/ row had maximum positive direct effect on grain yield followed by 100 -kernel weight, ear length and number of rows/ ear. Ibrahim (2004) reported that both number of kernels/ row and 100-kernel weight had the highest positive direct effects on grain yield variation under three $\mathrm{N}$-levels and combined data.

The aims of this work were to investigate the phenotypic correlation coefficients between grain yield/ plant and its contributing characters as well as to determine the relative importance for each of ear diameter, ear length, number of kernels/ row and 100-kernel weight to grain yield variation in $\mathrm{F}_{2}$ generations of four yellow maize crosses under two planting dates.

\section{MATERIAL AND METHODS}

The experimental work of this study was carried out at the Agricultural Research Station of Faculty of Agriculture, Ain Shams University, Shalakan, Kalubia Governorate, Egypt. Six inbred lines of yellow maize were used in this study. Three of them namely; CML.326 $\left(\mathrm{P}_{1}\right)$, CML.325 $\left(\mathrm{P}_{2}\right)$ and CML.134 $\left(\mathrm{P}_{3}\right)$ were introduced from CIMMYT. The remain- ing three inbred lines, viz. CM.202 $\left(\mathrm{P}_{4}\right)$, Roh.43Ht,B $\left(\mathrm{P}_{5}\right)$ and BS-10-8 $\left(\mathrm{P}_{6}\right)$ were kindly provided by the Maize Research Department, Field Crops Research Institute, Agricultural Research Center, Ministry of Agriculture and Land Reclamation, Giza, Egypt. The $F_{1}$ and $F_{2}$ seeds of the four crosses i.e. CML.134 X BS-10-8 (cross 1), CM.202 X Roh.43Ht, B (cross 2), CML.326 X CML.325 (cross 3) and CML.326 X BS-10-8 (cross 4), were formed during 2001 and 2002 seasons. In 2003 summer season, $F_{2}$ plants of the four crosses were grown in separate experiments under the two planting dates (14 ${ }^{\text {th }}$ May and $29^{\text {th }}$ June). Each experiment was arranged in a Randomized Complete Block Design with four replicates. Each replication consisted of 13 ridges of $\mathrm{F}_{2}$ plants. Each ridge included 16 single plants, $25 \mathrm{~cm}$ apart within ridges of $70 \mathrm{~cm}$ width. All agricultural practices were applied as recommended. Data were recorded on 484 guarded plants for $F_{2}$ generation for grain yield/ plant, 100-kernel weight, number of kernels/ row, number of rows/ ear, ear diameter, ear length, ear height, plant height and days to silking. The phenotypic correlation coefficients were calculated as described by Snedecor and Cochran (1981) for all possible pairs of the studied characters including grain yield/ plant under the two planting dates. To obtain more information about the relative contribution of specific character to grain yield/ plant and remaining characters, the path coefficient analysis was performed for each cross. The partitioning correlation coefficient into direct and indirect effects at phenotypic level was made by determining path coefficient using the method proposed by Dewey and Lu (1959). 


\section{RESULTS AND DISCUSSION}

\section{1- Correlation studies}

The phenotypic correlation coefficient provides important information about interrelationships between two or more of yield attributes by which the breeder can design a successful program to improve the yield capacity of maize. The phenotypic correlation coefficients estimated from the $\mathrm{F}_{2}$ generation for each cross between all possible pairs of characters including grain yield for both planting dates, obtained results are recorded in Tables (1 and 2). For cross 1 the grain yield under normal planting date showed positive significant correlations with each of ear diameter, ear length, number of kernels/ row, 100-kernel weight, ear height and number of rows/ ear while, under late planting date it showed positive significant correlations with each of number of kernels/ row, ear diameter, ear length, 100-kernel weight, number of rows/ ear, ear height and days to silking. In cross 2 , it gave positive and significant correlations with each of ear length, ear diameter, number of kernels, number of row/ ear and ear height while under late planting date it gave significant positive correlations with each of ear diameter, number of kernels/ row, 100-kernel weight, ear length and number of row/ ear. In cross 3, under normal planting date it showed significant positive correlations with each of ear diameter, ear length, number of kernels/ row, 100kernel weight, plant height, number of rows/ ear, ear height and 100-kernel weight while, under late planting date it gave significant positive correlations with each of number of kernels/ row, ear diameter, ear length, 100-kernel weight, number of rows/ ear and days to silking. In cross 4 , it gave significant positive correlations with each of ear diameter, number of kernels/ row, ear length, number of rows/ ear, plant height, ear height and 100-kernel weight, while under late planting date it gave significant positive correlations with each of 100-kernel weight, number of kernels/ row, ear diameter, ear length and number of rows/ ear.

From the above mentioned results it can be briefly concluded that correlation between grain yield per plant and other studied traits in the four crosses were found to be highly significant or significant for all traits under the two planting dates with few exceptions. Highest values of these correlations were mostly reported for the characters of ear diameter and number of kernels/ row followed by ear length and 100-kernel weight. The other characters showed low values (Tables1 and 2). Results indicate that selection considered most these characters simultaneously may be effective in improving grain yield/ plant especially those characters which had high heritability estimates (data not shown). From these results it can be concluded that ear diameter, ear length, number of kernels/ row and number of rows/ ear were more important contributions of yield component towards grain yield under normal planting date. On the other hand, under late planting date the number of kernels/ row, ear diameter, 100-kernel weight, ear length and number of rows/ ear were the more important contributions towards grain yield/ plant. Similar results were found by Amin et al (2003) who reported positive highly significant correlations with each of ear length, ear diameter, number of kernels/ row, 100-kernel weight, plant 
Table 1. Phenotypic correlation coefficients between grain yield per plant and eight contributing traits in $\mathrm{F}_{2}$ generation of the four yellow maize crosses at normal planting date.

\begin{tabular}{|c|c|c|c|c|c|c|c|c|c|}
\hline Character & Cross $^{+}$ & $\mathrm{X}_{2}$ & $\mathrm{X}_{3}$ & $\mathrm{X}_{4}$ & $\mathrm{X}_{5}$ & $\mathrm{X}_{6}$ & $\mathrm{X}_{7}$ & $\mathrm{X}_{8}$ & $\mathrm{X}_{9}$ \\
\hline Silking & 1 & -0.025 & $-0.212 * *$ & -0.068 & -0.080 & 0.039 & $-0.098 *$ & $-0.127 * *$ & -0.088 \\
\hline date & 2 & -0.047 & -0.032 & -0.015 & 0.023 & 0.053 & 0.024 & -0.008 & 0.000 \\
\hline \multirow[t]{2}{*}{$\left(\mathrm{X}_{1}\right)$} & 3 & -0.062 & -0.079 & $-0.115^{*}$ & $-0.113 *$ & -0.004 & $-0.096 *$ & -0.026 & $-0.168 * *$ \\
\hline & 4 & $-0.365^{* *}$ & $-0.257 * *$ & $-0.170 * *$ & $-0.141 * *$ & -0.076 & $-0.130 * *$ & 0.039 & $-0.188 * *$ \\
\hline Plant & 1 & & $0.256^{* *}$ & 0.037 & -0.001 & 0.009 & 0.041 & 0.064 & -0.001 \\
\hline height & 2 & & $0.446^{* *}$ & 0.036 & 0.073 & 0.089 & 0.007 & -0.057 & 0.046 \\
\hline \multirow[t]{2}{*}{$\left(\mathrm{X}_{2}\right)$} & 3 & & $0.467 * *$ & $0.111^{*}$ & $0.219 * *$ & 0.075 & 0.022 & 0.040 & $0.218^{* *}$ \\
\hline & 4 & & $0.589 * *$ & $0.141 * *$ & $0.120 * *$ & 0.050 & 0.063 & -0.700 & $0.158 * *$ \\
\hline Ear & 1 & & & $0.171 * *$ & $0.170 * *$ & 0.062 & $0.171 * *$ & $0.149 * *$ & $0.174 * *$ \\
\hline height & 2 & & & 0.067 & 0.079 & 0.041 & 0.038 & 0.041 & $0.093^{*}$ \\
\hline \multirow[t]{2}{*}{$\left(\mathrm{X}_{3}\right)$} & 3 & & & $0.091 *$ & $0.116^{*}$ & $0.091^{*}$ & -0.004 & 0.003 & $0.136^{* *}$ \\
\hline & 4 & & & 0.079 & $0.147 * *$ & $0.109 *$ & 0.068 & -0.013 & $0.145^{* *} *$ \\
\hline Ear & 1 & & & & $0.546 * *$ & 0.052 & $0.610 * *$ & $0.232 * *$ & $0.723 * *$ \\
\hline length & 2 & & & & $0.284 * *$ & $0.325^{* *}$ & $0.576^{* *}$ & 0.005 & $0.680 * *$ \\
\hline \multirow[t]{2}{*}{$\left(\mathrm{X}_{4}\right)$} & 3 & & & & $0.495 * *$ & $0.199 * *$ & $0.608^{* * *}$ & 0.077 & $0.765 * *$ \\
\hline & 4 & & & & $0.405 * *$ & $0.257 * *$ & $0.556^{* *}$ & 0.024 & $0.664 * *$ \\
\hline \multirow{4}{*}{$\begin{array}{c}\text { Ear } \\
\text { diameter } \\
\left(\mathrm{X}_{5}\right)\end{array}$} & 1 & & & & & 0.058 & $0.507 * *$ & $0.215^{* *}$ & $0.744 * *$ \\
\hline & 2 & & & & & $0.417 * *$ & $0.321 * *$ & -0.015 & $0.610^{* *}$ \\
\hline & 3 & & & & & $0.119 * *$ & $0.494 * *$ & $0.095^{*}$ & $0.781 * *$ \\
\hline & 4 & & & & & $0.438 * *$ & $0.498 * *$ & 0.062 & $0.765 * *$ \\
\hline \multirow{4}{*}{$\begin{array}{l}\text { No. of rows } \\
\text { per ear } \\
\left(\mathrm{X}_{6}\right)\end{array}$} & 1 & & & & & & $0.096^{*}$ & $-0.093^{*}$ & $0.099^{*}$ \\
\hline & 2 & & & & & & $0.529 * *$ & -0.049 & $0.454 * *$ \\
\hline & 3 & & & & & & $0.161 * *$ & 0.080 & $0.154 * *$ \\
\hline & 4 & & & & & & $0.486 * *$ & $-0.136^{* *}$ & $0.441 * *$ \\
\hline \multirow{4}{*}{$\begin{array}{c}\text { No. of ker- } \\
\text { nels } \\
\text { per row } \\
\left(\mathrm{X}_{7}\right)\end{array}$} & 1 & & & & & & & $0.176 * *$ & $0.651 * *$ \\
\hline & 2 & & & & & & & -0.021 & $0.573^{*} *$ \\
\hline & 3 & & & & & & & -0.022 & $0.663 * *$ \\
\hline & 4 & & & & & & & -0.009 & $0.678 * *$ \\
\hline \multirow{4}{*}{$\begin{array}{c}\text { 100-kernel } \\
\text { weight } \\
\left(\mathrm{X}_{8}\right)\end{array}$} & 1 & & & & & & & & $0.253^{* *}$ \\
\hline & 2 & & & & & & & & -0.055 \\
\hline & 3 & & & & & & & & $0.128 * *$ \\
\hline & 4 & & & & & & & & $0.099 *$ \\
\hline \multirow{4}{*}{$\begin{array}{l}\text { Grain yield } \\
\text { per plant } \\
\left(\mathrm{X}_{9}\right)\end{array}$} & 1 & & & & & & & & \\
\hline & 2 & & & & & & & & \\
\hline & 3 & & & & & & & & \\
\hline & 4 & & & & & & & & \\
\hline
\end{tabular}

Where: $*$ and $* *$ denote significance at 0.05 and 0.01 levels of probability, respectively. $+=$ Cross 1, 2, 3 and 4 are; CML.134 BS-10-8, CM.202 Roh.43Ht,B, CML.326 CML.325 and CML.326 BS-10-8, respectively. 
Table 2. Phenotypic correlation coefficients between grain yield per plant and eight contributing traits in $\mathrm{F}_{2}$ generation of the four yellow maize crosses at late planting date.

\begin{tabular}{|c|c|c|c|c|c|c|c|c|c|}
\hline Character & $\mathrm{Cross}^{+}$ & $\mathrm{X}_{2}$ & $X_{3}$ & $X_{4}$ & $\mathrm{X}_{5}$ & $\mathrm{X}_{6}$ & $\mathrm{X}_{7}$ & $\mathrm{X}_{8}$ & $\mathrm{X}_{9}$ \\
\hline Silking & 1 & -0.083 & -0.081 & 0.041 & 0.076 & -0.030 & $0.117 *$ & $0.122 *$ & $0.092 *$ \\
\hline date & 2 & -0.025 & -0.072 & -0.015 & -0.050 & -0.009 & 0.009 & $-0.104 *$ & -0.034 \\
\hline \multirow[t]{2}{*}{$\left(\mathrm{X}_{1}\right)$} & 3 & $-0.160 * *$ & -0.270 & $0.091 *$ & 0.062 & 0.010 & 0.055 & 0.064 & $0.097^{*}$ \\
\hline & 4 & 0.024 & 0.054 & -0.029 & -0.047 & 0.004 & 0.014 & 0.010 & -0.130 \\
\hline Plant & 1 & & $0.252 * *$ & 0.060 & -0.015 & $0.129 * *$ & 0.005 & 0.026 & 0.012 \\
\hline height & 2 & & $0.265^{* *}$ & -0.002 & -0.056 & 0.016 & 0.004 & 0.017 & 0.007 \\
\hline \multirow[t]{2}{*}{$\left(\mathrm{X}_{2}\right)$} & 3 & & $0.532 * *$ & -0.046 & -0.089 & 0.015 & -0.043 & -0.001 & -0.063 \\
\hline & 4 & & $0.341 * *$ & 0.058 & -0.025 & 0.059 & -0.032 & 0.067 & 0.041 \\
\hline Ear & 1 & & & -0.074 & -0.079 & -0.074 & $0.117 *$ & $0.122 * *$ & $0.092 *$ \\
\hline height & 2 & & & $-0.157 * *$ & -0.064 & -0.043 & -0.072 & -0.013 & $-0.108^{*}$ \\
\hline \multirow[t]{2}{*}{$\left(\mathrm{X}_{3}\right)$} & 3 & & & 0.040 & -0.026 & $0.127 * *$ & 0.004 & -0.021 & 0.059 \\
\hline & 4 & & & 0.037 & -0.069 & 0.016 & -0.048 & 0.014 & 0.021 \\
\hline Ear & 1 & & & & $0.253 * *$ & $0.120 * *$ & $0.246^{* *}$ & 0.036 & $0.356^{* *}$ \\
\hline length & 2 & & & & $0.112^{*}$ & $0.103 *$ & $0.113^{*}$ & $0.139 * *$ & $0.254 * *$ \\
\hline \multirow[t]{2}{*}{$\left(\mathrm{X}_{4}\right)$} & 3 & & & & $0.379 * *$ & 0.045 & $0.529 * *$ & $0.242 * *$ & $0.619 * *$ \\
\hline & 4 & & & & $0.375^{* *}$ & $0.138 * *$ & $0.491 * *$ & $0.518 * *$ & $0.583 * *$ \\
\hline \multirow{4}{*}{$\begin{array}{c}\text { Ear } \\
\text { diameter } \\
\left(\mathrm{X}_{5}\right)\end{array}$} & 1 & & & & & $0.141 * *$ & $0.500 * *$ & $0.198 * *$ & $0.652 * *$ \\
\hline & 2 & & & & & $0.203^{* *}$ & $0.486^{* *}$ & $0.438 * *$ & $0.543 * *$ \\
\hline & 3 & & & & & 0.022 & $0.418 * *$ & $0.207 * *$ & $0.648 * *$ \\
\hline & 4 & & & & & $0.251 * *$ & $0.474 * *$ & $0.485 * *$ & $0.601 * *$ \\
\hline \multirow{4}{*}{$\begin{array}{c}\text { No. of rows } \\
\text { per ear } \\
\left(\mathrm{X}_{6}\right)\end{array}$} & 1 & & & & & & $0.197 * *$ & 0.024 & $0.224 * *$ \\
\hline & 2 & & & & & & $0.185^{* *} *$ & $0.193 * *$ & $0.163 * *$ \\
\hline & 3 & & & & & & $0.183 * *$ & $0.138 * *$ & $0.157 * *$ \\
\hline & 4 & & & & & & $0.124 * *$ & $0.159 * *$ & $0.230 * *$ \\
\hline \multirow{4}{*}{$\begin{array}{c}\text { No. of ker- } \\
\text { nels } \\
\text { per row } \\
\left(\mathrm{X}_{7}\right)\end{array}$} & 1 & & & & & & & $0.181 * *$ & $0.692 * *$ \\
\hline & 2 & & & & & & & $0.319 * *$ & $0.538 * *$ \\
\hline & 3 & & & & & & & $0.380 * *$ & $0.702 * *$ \\
\hline & 4 & & & & & & & $0.609 * *$ & $0.651 * *$ \\
\hline \multirow{4}{*}{$\begin{array}{c}\text { 100-kernel } \\
\text { weight } \\
\left(\mathrm{X}_{8}\right)\end{array}$} & 1 & & & & & & & & $0.241 * *$ \\
\hline & 2 & & & & & & & & $0.383 * *$ \\
\hline & 3 & & & & & & & & $0.463 * *$ \\
\hline & 4 & & & & & & & & $0.681 * *$ \\
\hline \multirow{4}{*}{$\begin{array}{c}\text { Grain yield } \\
\text { per plant } \\
\left(\mathrm{X}_{9}\right)\end{array}$} & 1 & & & & & & & & \\
\hline & 2 & & & & & & & & \\
\hline & 3 & & & & & & & & \\
\hline & 4 & & & & & & & & \\
\hline
\end{tabular}

Where: $*$ and $* *$ denote significance at 0.05 and 0.01 levels of probability, respectively. $+=$ Cross 1, 2, 3 and 4 are; CML.134 BS-10-8, CM.202 Roh.43Ht,B, CML.326 CML.325 and CML.326 BS-10-8, respectively. 
height, ear height and days to silking. Also, our results are in harmony with those obtained by Salama et al (1994); Soliman et al (1999); El Sheikh (1999); Mohamed et al (2002) and Ibrahim (2004).

Regarding ear diameter under normal planting date it gave positive and significant correlations with each of number of kernels/ row, number of rows/ ear with the exception of cross 1, ear length, ear height with the exception of cross 2 , plant height with the exception of crosses 1 and 2 , and 100-kernel weight with the exception of crosses 2 and 4. Meanwhile, it was correlated negatively and significantly with days to silking with the exception of crosses 1 and 2. Under late planting date there were positive significant correlations with each of number of kernels/ row, ear length, 100-kernel weight and number of rows/ ear, meanwhile it was correlated insignificantly with other traits. Similar results are obtained by Nawar $\boldsymbol{e t}$ al (1995); El Sheikh (1999); Amin et al (2003) and Ibrahim (2004).

Ear length under normal planting date showed positive significant correlations with each of number of kernels/ row, ear diameter and number of rows/ ear and also with 100-kernel weight only for cross 1 , ear height with the exception of crosses 2 and 4, plant height with the exception of crosses 1 and 2. Meanwhile, it was correlated negatively and significantly with days to silking with the exception of crosses 1 and 2. Under late planting date it showed positive significant correlations with each of number of kernels/ row, ear diameter, number of rows/ ear with the exception of cross 3 , 100-kernel weight with the exception of cross 1 and days to silking only for cross 3 , while it was correlated negatively and significantly with ear height only for cross 2 . The values of correlations at late planting date were lower than those at normal planting date. Our results are in harmony with those obtained by Salama et al (1994); Soliman et al (1999) and Alvi et al (2003).

Concerning number of kernels/ row positive correlations coefficients were found under normal planting date between it and each of ear length, ear diameter, number of rows/ ear, 100-kernel weight only for cross 1 , ear height only for cross 1. Meantime, it was correlated negatively and significantly with days to silking with the exception of cross 2 . On the other hand, under late planting date, it showed significant correlations with ear diameter, ear length, number of rows/ ear, ear height and days to silking only for cross 1. Such results are in accordance with the findings of Sary et al (1990); Soliman et al (1999); El Sheikh (1999) and Alvi et al (2003).

100-kernel weight under normal planting date showed positive significant correlations with each of number of kernels/ row, ear diameter, ear length, ear height only for cross 1 , while it showed negative significant correlations with number of rows/ ear only for cross 4 and days to silking only for cross 1 . On the other side, under late planting date, it showed significantly and positively correlations with each of number of kernels/ row, number of rows/ ear, ear diameter, ear length with the exception of cross 1 , ear height and days to silking only for cross 1 while, it shown negative significant correlation with days to silking only for cross 2. Previous results of El Sheikh (1999); Hassan (2000); Amin et al (2003) and Ibrahim (2004) indicated also positive significant correlations be- 
tween 100-kernel weight and one or more of number of kernels/ row, number of rows/ ear, ear diameter and ear length. In this respect, Ashmawy (2003) reported that ear length, ear diameter, number of kernels/ row and 100-kernel weight were the most important contributing variables in the total variability of grain yield/ plant.

\section{2- Path coefficient analysis}

Path coefficient analysis was estimated from each of planting date to study the direct and indirect effects of various yield components on grain yield/ plant as well as the relative importance of these components as selection criteria.

The traits taken into consideration as yield contributors in this study are ear diameter, ear length and number of kernels/ row at normal planting date while, at late planting date they were number of kernels/ row, ear diameter, 100-kernel weight and ear length. However, under normal planting date the values of the direct and indirect effects of these traits on grain yield/ plant variation (Table 3) showed that ear diameter had the highest positive direct effects for the crosses 1,3 and 4 while in cross 2 ; the ear length had the first rank. On the other side, the indirect effects of ear diameter through either ear length or number of kernels/ row were

Table 3. Partitioning of the phenotypic correlation coefficient between grain yield and its contributing traits in $\mathrm{F}_{2}$ population of the four yellow maize crosses at normal planting date.

\begin{tabular}{|lllll|}
\hline \multirow{2}{*}{ Source of variation } & \multicolumn{4}{c|}{ Effects } \\
\cline { 2 - 6 } & Cross 1 & Cross 2 & Cross 3 & Cross 4 \\
\hline 1- Ear length vs. yield per plant & & & & \\
Direct effect & 0.350 & 0.461 & 0.423 & 0.321 \\
Indirect effect via ear diameter & 0.243 & 0.121 & 0.243 & 0.208 \\
Indirect effect via No. of kernels / row & 0.129 & 0.098 & 0.099 & 0.136 \\
\hline Total & 0.722 & 0.680 & 0.765 & 0.664 \\
\hline 2- Ear diameter vs. yield per plant & & & & \\
Direct effect & 0.445 & 0.425 & 0.491 & 0.513 \\
Indirect effect via ear length & 0.191 & 0.131 & 0.209 & 0.130 \\
Indirect effect via No. of kernels / row & 0.107 & 0.055 & 0.081 & 0.122 \\
\hline Total & 0.744 & 0.611 & 0.781 & 0.765 \\
\hline 3- Number of kernels vs. yield per plant & & & & \\
Direct effect & 0.212 & 0.171 & 0.163 & 0.244 \\
Indirect effect via ear length & 0.214 & 0.266 & 0.257 & 0.178 \\
Indirect effect via ear diameter & 0.226 & 0.136 & 0.243 & 0.255 \\
\hline Total & 0.651 & 0.573 & 0.663 & 0.678 \\
\hline
\end{tabular}


positive and via ear length were higher than those of via number of kernels/ row in all crosses. The direct and joint effects for each of ear length, ear diameter and number of kernels/ row on plant yield variation are presented in Table (4). Data of crosses indicated that the highest main sources of grain yield variation in order of relative importance are the joint effects for direct effect for ear diameter followed by the joint effect of ear length through ear diameter for crosses 1, 3 and 4 while they were ear length followed by the direct effect of ear diameter for cross 2 . The total contribution of these mentioned traits directly and jointly were of $67.11 \%$ to $81.51 \%$. In most cases, it is worthy to note that the direct effect of ear diameter and ear length as well as joint effect of ear length through ear diameter proved to be the major grain yield contributors at normal planting date. In this respect, Akhtar et al (1999); Hassan (2000) and Ashmawy (2003) revealed that ear diameter and/or ear length are considered as the main component of plant grain yield variation. Therefore, it can be concluded from these results that ear diameter and ear length are the main components of plant grain yield variation under normal planting date and they seemed to be the most effective selection criteria in maize breeding program aiming at high grain yield capacity. On the other hand, data of late planting date (Table 5) for crosses 1 and 2 showed that number of kernels/ row had the highest positive direct effects while, in crosses 3 and 4, the ear diameter or 100-kernel weight had the highest positive direct effects. On the other side, the indirect effects of ear length through either ear diameter, number of kernels/ row or 100-kernel weight were positive and via number of kernels/ row were higher than those of via ear diameter and via 100-kernel in all crosses except cross 4 whereas, the indirect effect via 100kernel had the highest value. The direct and joint effects for each of ear length, ear diameter, number of kernels/

Table 4. Relative importance (direct and joint effects) in percent of grain yield variation in $\mathrm{F}_{2}$ population of the four yellow maize crosses at normal planting date.

\begin{tabular}{|c|c|c|c|c|c|c|c|c|c|}
\hline \multirow{2}{*}{\multicolumn{2}{|c|}{ Source of variation }} & \multicolumn{2}{|c|}{ Cross 1} & \multicolumn{2}{|c|}{ Cross 2} & \multicolumn{2}{|c|}{ Cross 3} & \multicolumn{2}{|c|}{ Cross 4} \\
\hline & & $\mathrm{CD}^{*}$ & $\mathrm{RI} \% * *$ & $\mathrm{CD}^{*}$ & $\mathrm{RI} \% * *$ & $\mathrm{CD}^{*}$ & $\mathrm{RI} \% * *$ & $\mathrm{CD}^{*}$ & $\mathrm{RI} \% * *$ \\
\hline 1 & Ear length $\quad\left(X_{1}\right)$ & 0.1225 & 12.25 & 0.2125 & 21.25 & 0.1789 & 17.89 & 0.1030 & 10.30 \\
\hline 2 & Ear diameter $\left(\mathrm{X}_{2}\right)$ & 0.1980 & 19.80 & 0.1806 & 18.06 & 0.2411 & 24.11 & 0.2632 & 26.32 \\
\hline 3 & Number of kernels / row $\left(\mathrm{X}_{3}\right)$ & 0.0449 & 4.49 & 0.0292 & 2.92 & 0.0266 & 2.66 & 0.0595 & 5.95 \\
\hline 4 & $\left(X_{1}\right) \times\left(X_{2}\right)$ & 0.1701 & 17.01 & 0.1113 & 11.13 & 0.2056 & 20.56 & 0.1334 & 13.34 \\
\hline 5 & $\left(\mathrm{X}_{1}\right) \times\left(\mathrm{X}_{3}\right)$ & 0.0905 & 9.05 & 0.0908 & 9.08 & 0.0838 & 8.38 & 0.0871 & 8.71 \\
\hline 6 & $\left(X_{2}\right) \times\left(X_{3}\right)$ & 0.0957 & 9.57 & 0.0467 & 4.67 & 0.0791 & 7.91 & 0.1247 & 12.47 \\
\hline 7 & Residual & 0.2783 & 27.83 & 0.3289 & 32.89 & 0.1849 & 18.49 & 0.2291 & 22.91 \\
\hline
\end{tabular}

Arab Univ. J. Agric. Sci., 13(2), 2005 
Table 5. Partitioning of the phenotypic correlation coefficient between grain yield and its contributing traits in $\mathrm{F}_{2}$ population of the four yellow maize crosses at late planting date.

\begin{tabular}{|lllll|}
\hline \multicolumn{1}{|c}{ Source of variation } & \multicolumn{4}{c}{ Effects } \\
\cline { 2 - 5 } & Cross 1 & Cross 2 & Cross 3 & Cross 4 \\
\hline 1- Ear length vs. yield per plant & & & & \\
Direct effect & 0.148 & 0.165 & 0.251 & 0.213 \\
Indirect effect via ear diameter & 0.094 & 0.035 & 0.141 & 0.099 \\
Indirect effect via No. of kernels/ row & 0.112 & 0.037 & 0.179 & 0.118 \\
Indirect effect via kernels weight & 0.003 & 0.016 & 0.047 & 0.153 \\
\hline Total & 0.357 & 0.254 & 0.619 & 0.584 \\
\hline 2- Ear diameter vs. yield per plant & & & & \\
Direct effect & 0.371 & 0.313 & 0.371 & 0.264 \\
Indirect effect via ear length & 0.037 & 0.019 & 0.095 & 0.080 \\
Indirect effect via No. of kernels/ row & 0.228 & 0.160 & 0.142 & 0.114 \\
Indirect effect via kernels weight & 0.014 & 0.052 & 0.041 & 0.144 \\
\hline Total & 0.650 & 0.544 & 0.649 & 0.602 \\
\hline 3- No. of kernels vs. yield per plant & & & & \\
Direct effect & 0.456 & 0.330 & 0.339 & 0.241 \\
Indirect effect via ear length & 0.036 & 0.019 & 0.133 & 0.104 \\
Indirect effect via ear diameter & 0.186 & 0.152 & 0.155 & 0.125 \\
Indirect effect via kernels weight & 0.013 & 0.038 & 0.075 & 0.180 \\
\hline Total & 0.691 & 0.538 & 0.702 & 0.651 \\
\hline 4- Kernels weight vs. yield per plant & & & & \\
Direct effect & 0.070 & 0.118 & 0.197 & 0.296 \\
Indirect effect via ear length & 0.005 & 0.023 & 0.061 & 0.110 \\
Indirect effect via ear diameter & & 0.137 & 0.077 & 0.128 \\
Indirect effect via No. of kernels/ row & 0.083 & 0.129 & 0.147 \\
\hline
\end{tabular}


row and 100-kernel weight on plant yield variation are presented in Table (6).

From these data it is indicated that the highest main sources of grain yield variation in order of relative importance are the joint effects for direct effects of number of kernels/ row in the crosses 1 and 2, for direct effects of ear diameter in the cross 3 and for direct effects of 100kernel weight in cross 4 .

The total contribution of these mentioned traits directly and jointly were of $43.49 \%$ to $72.51 \%$. In most cases, it is worthy to note that the direct effect of number of kernels/ row and ear diameter as well as joint effect of ear diameter through number of kernels/ row proved to be the major grain yield contributors at late planting date. From all the above mentioned results it can be briefly concluded that grain yield/ plant under the two planting dates correlated positively and significantly with each of ear diameter, ear length, number of kernels/ row, 100-kernel weight, number of rows/ ear and ear height. Path coefficient analysis estimates indicated that ear diameter; ear length and ear length through its indirect effects via ear diameter are considered as the most important sources of plant grain yield variation.

Table 6. Relative importance (direct and joint effects) in percent of grain yield variation in $\mathrm{F}_{2}$ population of the four yellow maize crosses at late planting date.

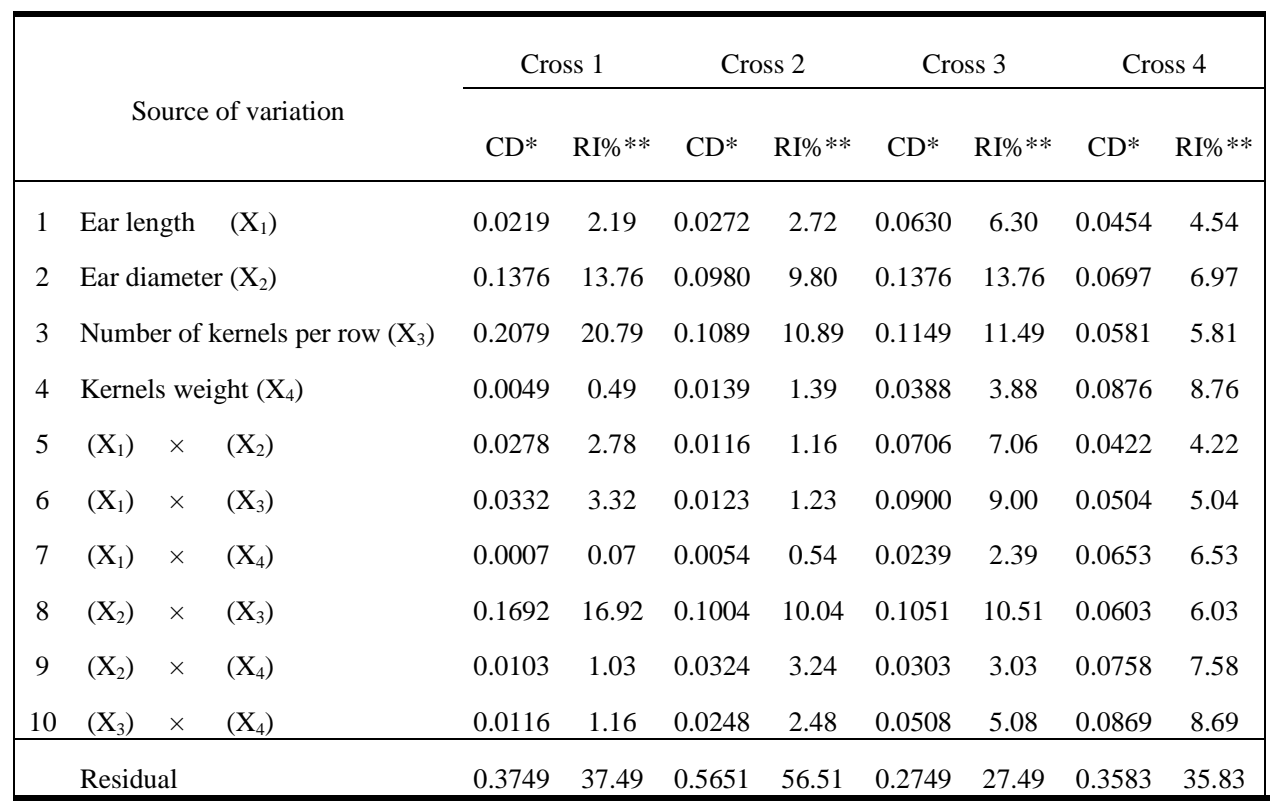

CD* denote coefficient of determination

$\mathrm{RI} \%$ ** denote relative Importance 


\section{REFERENCES}

Abd El Aty, M.S. and Y.S. Katta (2002). Estimation of heterosis and combining ability for yield and other agronomic traits in maize hybrids (Zea mays L.). J. Agric. Sci., Mansoura Univ., 27 (8): 5137-5146.

Akhtar, M.; Sh. Ahmad; S. Mohsin and T. Mahmood (1999). Interactive effect of phosphorus and potassium nutrition on the growth and yield of hybrid maize (Zea mays, L). Pakistan J. of Boil. Sci. 2 (1): 240 - 241.

Alvi, M.B.; M. Rafique; M.Sh. Tariq; A. Hussain; T. Mahmood and M. Sarwar (2003). Hybrid vigor of some quantitative characters in maize (Zea mays L.). Pakistan J. of Biol. Sci.6(2): 139-141.

Amin, Amal. Z.; H.A. Khalil and R.K. Hassan (2003). Correlation studies and relative importance of some plant characters and grain yield in maize single crosses. Arab Univ. J. Agric. Sci., Ain Shams Univ., Cairo, 11 (1): 181-190.

Ashmawy, F. (2003). Using some multivariate procedures and response curve analysis in maize. J. Agric. Sci., Mansoura Univ., 28 (10): 7107-7121.

Dewey, D.R. and K.H. Lu (1959). A correlation and path coefficient analysis of components of crested wheatgrass seed production. Agron. J. 51: 515-518.

El Beially, I.E. (2003). Genetic analysis of yield characters in yellow maize inbred lines.Zagazig J. Agric. Res. 30(3):677689.

El Sheikh, F.T.Z. (1999). Evaluation of seven maize varieties (Zea mays L.) for some growth characteristics, grain yield and its quality. Annals of Agric. Sci., Moshtohor, 37(2): 881-896.
Hassan, A.A. (2000). Effect of plantpopulation density on yield and yield components of eight Egyptian maize hybrids. Bull. Fac. Agric. Cairo Univ., 51:1-16. Ibrahim, K.I.M. (2004). Evaluation of genetic variances, heritabilities, correlation and path coefficient analysis for grain yield and its contributors in maize hybrids under different N-levels. A $\boldsymbol{a} \boldsymbol{a b}$ Univ. J. Agric. Sci., Ain Shams Univ., Cairo, 12(1): 185-200.

Mohamed, Amal. Z.A. (2003). Heterosis and Combining Ability for Yield and its Components in some Single Crosses of Maize under Different Treatments. pp 1-3. Ph.D. Thesis, Fac. of Agric., Ain Shams Univ., Egypt.

Mohamed, Samia, G.A.; Sohier. M.S. Amer and S.A. Salama (2002). Estimating predication equations of yield and its characters in maize using some macro climatic and micro environmental factors. J. Agric. Sci., Mansoura Univ., 27 (7): 4355-4370.

Nawar, A.A.; F.A. Hendawy; Sh.A. ElShamarka and M.M.M. Asfour (1995). Genetic variance components in Giza-2 maize population. Minufiya J. Agric. Res. 20 (2): 423-439.

Salama, F.A.; H. El-M. Gado; A. Sh. Goda and S.E. Sadek (1994). Correlation and path coefficient analysis in eight white maize (Zea mays L.) hybrid characters. Minufiya J. Agric. Res., 19 (6): 3009-3020.

Sary, G.A.; A.A. El Hosary; S.A. Mohamed and A.A. Abd EI Sattar (1990). Studies on combining ability and heterosis in maize (Zea mays, L.) III- Association studies. Egypt. J. Agron., 15 (1-2): 1-8.

Snedecor, G.W. and W.G. Cochran (1981). Statistical methods. $6^{\text {th }}(E d), p p$. 
175-191. Iowa Stat. Univ., Press. Ames, Iowa, U.S.A.

Soliman, F.H.; G.A. Morshed; M.M.A. Ragheb and M.Kh. Osaman (1999). Correlations and path coefficient analysis in four yellow maize hybrids grown under different levels of plant population densities and nitrogen fertilization. Bull. Fac. Agric. Cairo Univ, 50: 639658.

بحلة اتحاد الجحامعات العربية للدراسات والبحوث الزراعية، جامعة عين شمس، القاهرة ، 13(2)، 327-339، 2005

معامل الأرتباط والمرور لأربعة هجن من الأرة الصفراء تحث ميعادين للزراعة

كمال عبد العزيز الشوني¹- ألقت حسن الباجوري 1- كمال إمام محمد إبراهيم1 -

[20]

$$
\begin{aligned}
& \text { سميز علي الأحمد } 1 \text { سمة } \\
& \text { 1- قسم المحاصيل - كلية الزراعة - جامعة عين شمس - شبرا الخيمة - القاهرة - مصر }
\end{aligned}
$$

أجريت هذه الدراسة بمحطة التجارب من مركز تحسين الذرة والقمح بالمكسيك

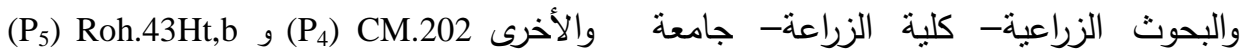
عين شمس- بشلقان- محافظة القلوبية خلال و الموسم الصيفي لأعوام 2001، 2002، موسم 2001 لنكوين بذور الهجن الفرديه وفي 2003 وذلك بهدف دراسة نأثنر ميعادين 2002 تم إجراء تلقيح ذاتي صناعي لنباتات للزراعة (العادي والمتأخر) على الإرنباطات الـ F1 بهدف الحصول على بذور الجيل الثاني

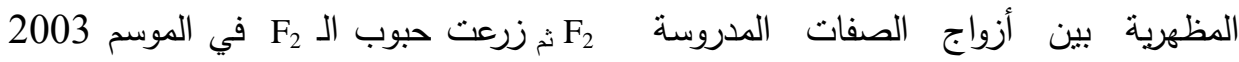
وتقدير معامل المرور للوقوف على الأهمية تحت ميعاديين للزراعة طبيعي أو عادي 14 النسبية لكل صفة من خلال تقدير مساهمة مايو ومنأخر 29 يونبو (تجربة لكل ميعاد) كل منها في تباين محصول النبات من وزرعت كل تجربة بتصميم القطاعات كاملة العشوائية في أربع مكرارات. وقد أجريت جميع لئن الحبوب تحت كل ميعاد للزراعة.

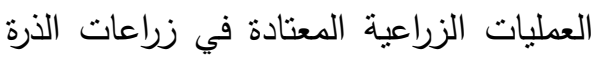

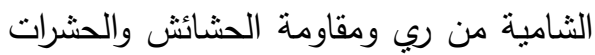
وخلافة حتى نضـج النباتات. تم أخذ القراءات والقياسات على 484 نبات من الجيل الثاني لصفات عدد الأيام من الزراعة حتى ظهور

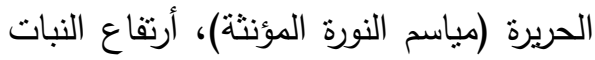

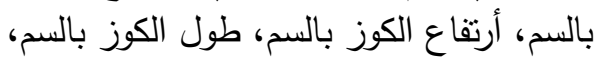

استخدمت في هذه الدراسة أربعة هجن

فردية وهي: الهجين الأول (P X P الثاني (P X P $)$ (P P والهجين الرابع (P X P $)$ ناتجة من التهجين بين ست سلالات نقية من الذرة الصفراء الثامية منها ثلاث سلالات (P $\left(P_{2}\right)$ CML.325, 
قطر الكوز بالسم، عدد الصفوف بالكوز، عدد وإرتقاع الكوز وعدد الأيام من الزراعة وحتى بإنى

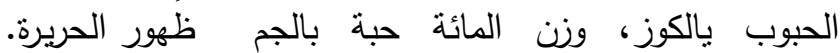

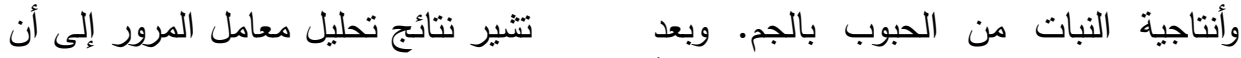

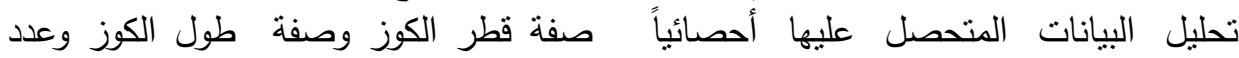

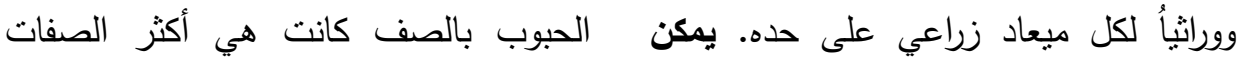

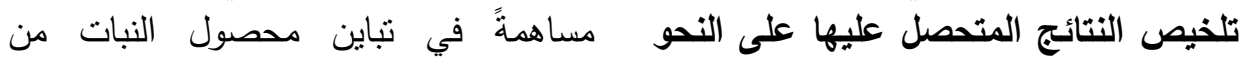
الحبوب تحت ميعاد الزراعة الطبيعي بينما فئس

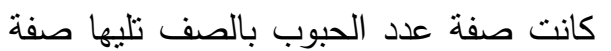

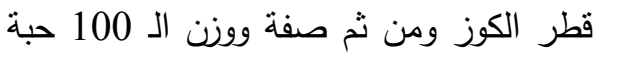
وأخيراً صفة طول طول الكوزمن أكثر الصفات

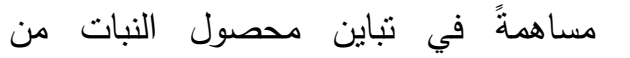
الح الحبوب تحت ميعاد الزراعة المتأخر ـ أبي أنه أنه

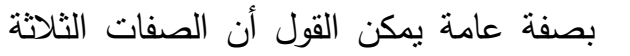

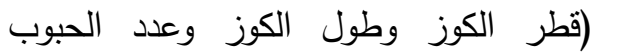

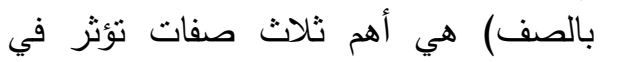
تباين محصول النبات من الحبوب تحت هذن فئ فئر الحبوب بالصف وقطر الكوز ووزن الـ 100 الدات ولدراسة.

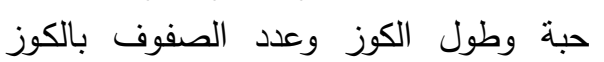

كان هنالك إرتباطاً موجباً ومعنوياً بين

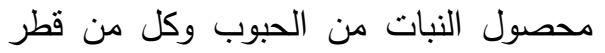

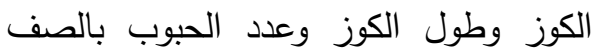
ووزن الـ 100 حبة وعدد الصفوف وعدد بالكوز بالكزي وإرتفاع الكوز وإرتفاع النبات وعدد الأيام من ون الندان

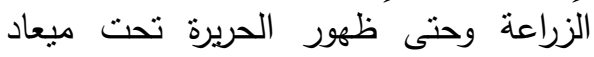
الزراعة العادي. بينما تحت ميعاد الزيأ الزراعة

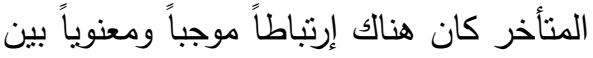
محصول النبات من الحبوب وكل من عدان عدئ

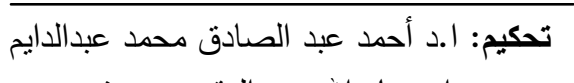
I.د جاد الله عبد المقصود مرشـد 